\title{
Comparison of urinary glycosaminoglycan excretion in rheumatoid arthritis, osteoarthritis, myocardial infarction, and controls
}

\author{
ALEXIS J CHUCK, JOHN MURPHY, JACQUELINE B WEISS, AND \\ DAVID M GRENNAN \\ From the Rheumatic Diseases Centre, University of Manchester, Hope Hospital, Eccles Old Road, Salford
}

SUMMARY Urinary glycosaminoglycan (GAG) excretion was measured in 24 patients with active $\stackrel{\circ}{\mathrm{G}}$ rheumatoid arthritis (RA) before and after treatment with conventional second-line agents. iv Urinary GAG excretion was also measured in normal controls, patients with osteoarthritis (OA), $\vec{\circ}$ and patients with acute myocardial infarction (MI). Total GAG excretion was increased in the ${ }^{N}$

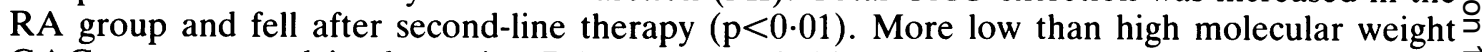
GAG was excreted in the active RA group, and this pattern was reversed after treatment. $\vec{T}$ Excretion of total, high and low molecular weight GAG in the OA group did not differ $\stackrel{D}{O}$ significantly from controls. Total GAG excretion was increased in the MI group when compared with controls $(\mathrm{p}<0.02)$ and consisted mainly of high molecular weight GAG. The serial measurement of urinary GAG provides a further index of disease activity and may help to $\vec{\oplus}$ monitor response to treatment.

Key words: serial measurements, alcian blue, disease activity.

Previous workers have shown that urinary excretion of sulphated glycosaminoglycans $(\mathrm{GAG})$ is increased in connective tissue disorders such as progressive systemic sclerosis ${ }^{1}$ and rheumatoid arthritis (RA). ${ }^{2}$ The amount of high molecular weight GAG and low molecular weight GAG excreted varies in different disorders and with disease activity. ${ }^{34}$ To establish whether measurement of urinary GAG excretion and the relative amounts of high and low molecular weight GAG provide a useful additional index of inflammatory disease activity, patients with RA were studied before and after commencing second-line drug therapy with chloroquine, gold, or D-penicillamine. The results of GAG excretion in RA were compared with GAG excretion in patients with osteoarthritis (OA), in patients after acute myocardial infarction (MI), and in normal controls. The $\mathrm{OA}$ and MI groups were chosen to study the effects of non-inflammatory joint disease and acute nonarticular tissue damage respectively on GAG excretion.

Accepted for publication 29 July 1985

Correspondence to $\mathrm{Dr} \mathrm{A} \mathrm{J}$ Chuck

*Present address: Harlow Wood Orthopacdic Hospital. Nr Mansfield, Notts NG18 4TH.

\section{Patients and methods}

All patients were attending one of two rheumatology departments or were inpatients. Serial assess- ments (RA patients) were performed by the sameo clinician, and the MI group was obtained from admissions to two ccronary care units. The controlo group comprised laboratory and medical personnelo with no history of joint disease, and patients with soft tissue rheumatism. No subject with significantô renal or hepatic impairment was included in the study. Patient numbers and ages are recorded in음 Table 1.

The RA patients all had definite or classical RA by American Rheumatism Association (ARA) N criteria. ${ }^{5}$ At each assessment the following para-o meters of disease activity were recorded: global $\tilde{O}$ clinical assessment $(0-3)$; duration of morning stiff- - W ness (EMS) (minutes); erythrocyte sedimentation rate (ESR) $(\mathrm{mm} / 1 \mathrm{st} \mathrm{h})$. Disease duration (range twoe months to 20 years, mean 6.7 years) at entry into the study and drug treatment were noted. Six out of the? 24 patients were taking no drugs or pure analgesics 0 only, the remaining 18 were taking non-steroidalo anti-inflammatory agents regularly, which were not 
Table 1 Characteristics of the groups (patients and controls) studied: numbers in each group and age range (mean) in years

\begin{tabular}{|c|c|c|c|c|c|c|}
\hline Group & $\begin{array}{l}\text { No in } \\
\text { group }\end{array}$ & $\begin{array}{l}\text { Age range } \\
\text { (mean) }\end{array}$ & Males & $\begin{array}{l}\text { Age range } \\
\text { (mean) }\end{array}$ & Females & $\begin{array}{l}\text { Age range } \\
\text { (mean) }\end{array}$ \\
\hline Rheumatoid arthritis & 24 & $\begin{array}{l}22-80 \\
(56 \cdot 5)\end{array}$ & 8 & $\begin{array}{l}31-74 \\
(60 \cdot 7)\end{array}$ & 16 & $22-80$ \\
\hline Osteoarthritis & 16 & $\begin{array}{l}42-79 \\
(66 \cdot 6)\end{array}$ & 5 & $\begin{array}{l}42-75 \\
(62 \cdot 4)\end{array}$ & 11 & $\begin{array}{l}57-79 \\
(68 \cdot 8)\end{array}$ \\
\hline Myocardial infarction & 21 & $\begin{array}{l}37-73 \\
(56 \cdot 1)\end{array}$ & 16 & $\begin{array}{l}41-73 \\
(56 \cdot 3)\end{array}$ & 5 & $\begin{array}{l}37-65 \\
(55 \cdot 6)\end{array}$ \\
\hline Controls & 30 & $\begin{array}{l}26-68 \\
(43 \cdot 7)\end{array}$ & 17 & $\begin{array}{l}27-68 \\
(43 \cdot 6)\end{array}$ & 13 & $\begin{array}{l}29-65 \\
(43.9)\end{array}$ \\
\hline
\end{tabular}

altered during the study period. Samples from the RA group were obtained while the patients were on a gelatin-free diet, as a concurrent study requiring hydroxyproline excretion estimation was in progress. The other groups were on normal diets. The OA patients had predominantly primary generalised disease with no evidence of inflammatory joint disease. They were assessed clinically, with radiological assessment of the affected joints and measurement of the ESR. Patients who had sustained an MI in the previous 24 hours were entered into the study after excluding those with joint disease or other inflammatory condition. Serial 'cardiac enzymes' (aspartate aminotransferase (AST) and lactate dehydrogenase (LDH)) and plasma viscosity or ESR were recorded. The height and weight of each subject were recorded, and the body surface area was calculated from a nomogram. Initially this was used to express hydroxyproline excretion, as it eliminated the effect of differing bone masses. It was retained in calculating GAG excretion, as we believe it also reflects the total connective tissue content of the body and hence turnover of GAG.

A single 24-hour urine sample was collected from each subject, except those in the RA group. From these, at least two specimens were obtained, one before commencing second-line treatment and a second after treatment had been established. Treatment periods ranged from two to 12 months, mean 18.6 weeks. In the MI group, to exclude the effects on renal function of transient hypotension postinfarction, the GAG:creatinine ratio was calculated on three successive days postinfarct. All samples were stored at $-20^{\circ} \mathrm{C}$ without preservative until assayed. Sample storage time did not affect GAG content and this has been the experience of other workers. $^{4}$

The urinary GAG content was measured before and after dialysis against distilled water. The method used was a modification of that developed by Whiteman ${ }^{6}$ and involves complex formation with the cationic dye alcian blue $8 \mathrm{GX}$. In this procedure a standard GAG solution $(200 \mu \mathrm{l})$ or centrifuged urine $(200 \mu \mathrm{l})$ was mixed with $4 \mathrm{ml}$ of freshly prepared $0.05 \% \mathrm{w} / \mathrm{v}$ alcian blue $8 \mathrm{GX}$ and $50 \mathrm{mM}$ $\mathrm{MgCl}_{2}$ in a $50 \mathrm{mM}$ sodium acetate buffer ( $\mathrm{pH} \mathrm{5 \cdot 8)}$. The mixture was equilibrated for two hours at room temperature and an alcian blue-GAG complex was separated by centrifugation at $2000 \mathrm{~g}$ for 20 minutes. The precipitate was washed twice with ethanol followed by centrifugation and then dissociated with a $5 \%$ solution of sodium dodecyl sulphate in distilled water $(4 \mathrm{ml})$. The absorbance of the resulting solution was measured in $1 \mathrm{~cm}$ microcuvettes at $620 \mathrm{~nm}$. The GAG content of the urine was determined by reference to a calibration curve constructed with chondroitin 4-sulphate as standard. The results are expressed as milligrams per square metre surface area per 24 hours. Total GAG represents results on undialysed urine, high molecular weight GAG the dialysed urine, and low molecular weight GAG the difference between these two values.

Differences between urinary GAG excretion in the RA and other groups were analysed by the Mann-Whitney U test; $p$ values of 0.05 or less were considered statistically significant. Two-tailed tests were applied to the analysis of GAG excretion in all groups. A one-tailed Wilcoxon's rank sum test was used for the analysis of changes in clinical assessment in the RA group.

\section{Results}

The results of urinary GAG excretion in the pretreatment RA group, OA, MI, and control groups are recorded in Table 2 and show that the mean total urinary GAG excretion was higher in the pretreatment RA group than in the controls, though this did not reach statistical significance. The crosssectional statistical analysis of total GAG was biased 
Table 2 Mean urinary GAG excretion and ranges (in brackets) in patient groups and controls: statistical analysis by the Mann-Whitney $U$ test

\begin{tabular}{|c|c|c|c|c|}
\hline Group & $\begin{array}{l}\text { Total } G A G \\
\text { excretion } \\
\left(\mathrm{mg} / \mathrm{m}^{2} / 24 \mathrm{~h}\right)\end{array}$ & $\begin{array}{l}\text { High mol. wt GAG } \\
\text { excretion } \\
\left(\mathrm{mg} / \mathrm{m}^{2} / 24 \mathrm{~h}\right)\end{array}$ & $\begin{array}{l}\text { Low mol. wt } G A G \\
\text { excretion } \\
\left(\mathrm{mg} / \mathrm{m}^{2} / 24 \mathrm{~h}\right)\end{array}$ & $\begin{array}{l}\text { Ratio } \\
\text { high:low } \\
\text { mol. wt GAG }\end{array}$ \\
\hline $\begin{array}{l}\text { Rheumatoid arthritis } \\
\text { (pretreatment) }\end{array}$ & $\begin{array}{l}32 \cdot 2 \\
(4 \cdot 6-155 \cdot 3) \\
\text { NS }\end{array}$ & $\begin{array}{l}15 \cdot 4 \\
(1 \cdot 5-48 \cdot 2) \\
\text { NS }\end{array}$ & $\begin{array}{l}16 \cdot 8 \\
(0 \cdot 4-137 \cdot 2) \\
\text { NS }\end{array}$ & 0.9 \\
\hline $\begin{array}{l}\text { Rheumatoid arthritis } \\
\text { (excluding two patients } \\
\text { see text) }\end{array}$ & $\begin{array}{l}34 \cdot 6 \\
(10 \cdot 1-155 \cdot 3) \\
p<0 \cdot 04\end{array}$ & $\begin{array}{l}16 \cdot 5 \\
(3 \cdot 7-48 \cdot 2) \\
p<0 \cdot 08\end{array}$ & $\begin{array}{l}18 \cdot 1 \\
(0 \cdot 6-137 \cdot 2) \\
p<0 \cdot 075\end{array}$ & 0.9 \\
\hline Osteoarthritis & $\begin{array}{l}22 \cdot 0 \\
(9 \cdot 0-75 \cdot 2) \\
\text { NS }\end{array}$ & $\begin{array}{l}12 \cdot 75 \\
(2 \cdot 8-52 \cdot 1) \\
\text { NS }\end{array}$ & $\begin{array}{l}9 \cdot 3 \\
(1 \cdot 4-41 \cdot 7) \\
\text { NS }\end{array}$ & $1 \cdot 4$ \\
\hline Myocardial infarction & $\begin{array}{l}40 \cdot 8 \\
(8 \cdot 3-182 \cdot 9) \\
p<0 \cdot 02\end{array}$ & $\begin{array}{l}35 \cdot 6 \\
(6 \cdot 3-117 \cdot 4) \\
p<0 \cdot 001\end{array}$ & $\begin{array}{l}5 \cdot 24 \\
(0-38 \cdot 7) \\
p<0 \cdot 01\end{array}$ & $6 \cdot 8$ \\
\hline Controls & $\begin{array}{l}20 \cdot 8 \\
(2 \cdot 6-58 \cdot 0)\end{array}$ & $\begin{array}{l}11 \cdot 7 \\
(1 \cdot 8-35 \cdot 3)\end{array}$ & $\begin{array}{l}8 \cdot 9 \\
(0 \cdot 1-36 \cdot 6)\end{array}$ & $1 \cdot 3$ \\
\hline
\end{tabular}

Table 3 Mean urinary GAG excretion and ranges (in brackets) in RA patients pre-and post-treatment: statistical analysis by the Mann-Whitney $U$ test

\begin{tabular}{|c|c|c|c|c|}
\hline Group & $\begin{array}{l}\text { Total GAG } \\
\text { excretion } \\
\left(\mathrm{mg} / \mathrm{m}^{2} / 24 \mathrm{~h}\right)\end{array}$ & $\begin{array}{l}\text { High mol. wt GAG } \\
\text { excretion } \\
\left(\mathrm{mg} / \mathrm{m}^{2} / 24 \mathrm{~h}\right)\end{array}$ & $\begin{array}{l}\text { Low mol. wt } G A G \\
\text { excretion } \\
\left(\mathrm{mg} / \mathrm{m}^{2} / 24 \mathrm{~h}\right)\end{array}$ & $\begin{array}{l}\text { Ratio } \\
\text { high:low } \\
\text { mol. wt } G A G_{0}\end{array}$ \\
\hline $\begin{array}{l}\text { Pretreatment RA } \\
\text { Post-treatment RA }\end{array}$ & $\begin{array}{l}32 \cdot 2(4 \cdot 6-155 \cdot 3) \\
15 \cdot 1 \quad(2 \cdot 5-52 \cdot 1) \\
\mathrm{p}<0 \cdot 01\end{array}$ & $\begin{array}{l}15 \cdot 4(1 \cdot 5-48 \cdot 2) \\
9 \cdot 0(2 \cdot 3-20 \cdot 4) \\
p<0 \cdot 04\end{array}$ & $\begin{array}{l}16 \cdot 8(0 \cdot 4-137 \cdot 2) \\
6 \cdot 0(0 \cdot 2-25 \cdot 2) \\
p<0 \cdot 25(\mathrm{NS})\end{array}$ & $\begin{array}{l}0.9 \\
1.5\end{array}$ \\
\hline
\end{tabular}

by the inclusion of two patients in the RA group whose values for total GAG of 4.6 and $6.6 \mathrm{mg} / \mathrm{m}^{2} / 24 \mathrm{~h}$ lay at the lower limit of the normal range. Articular disease activity in one was low, and the reasons for commencing second-line drug therapy had been the - presence of systemic features, and in the other articular disease activity remained unchanged by second-line therapy. If these two values are excluded from the cross-sectional statistical analysis, the difference between the pretreatment RA group and controls becomes statistically significant at the $5 \%$ level. There was no difference in total GAG excretion in those RA patients in the pretreatment group on non-steroidal anti-inflammatory drugs compared with those on no drugs or pure analgesics only. The high and low molecular weight GAG fractions were excreted in approximately the same amounts in the pretreatment RA group (ratio 'high' to 'low' 0.9 ), whereas in the control group there was a predominance of high molecular weight GAG (ratio 'high' to 'low' 1.3) excreted. Urinary excretion of total, high and low molecular weight GAG fell in the post-treatment RA group; the total and high molecular weight GAG excreted reached statistical significance compared with the pretreat- ment group, but the low molecular weight GAG did not. This was because of the wide range in this $\overrightarrow{\overrightarrow{0}}$ group. The proportion of high to low molecular $\exists$ weight GAG excreted in the post-treatment RA group increased to resemble the control group (ratio 'high' to 'low' 1.5) (Table 3).

There was an overall fall in the disease activity as measured by clinical assessment, duration of morning stiffness, and ESR (Table 4) in the posttreatment RA group when compared with the pretreatment values, and this reached statistical significance in the clinical assessment and ESR but

Table 4 Clinical assessment pre-and post-treatment in RA group: statistical analysis by Wilcoxon's rank sum test (one-tailed)

\begin{tabular}{llll}
\hline Group & $\begin{array}{l}\text { Mean global } \\
\text { clinical } \\
\text { assessment }\end{array}$ & $\begin{array}{l}\text { Duration morning } \begin{array}{l}\text { ESR } \\
\text { stiffness } \\
\text { (minutes) }\end{array} \\
(\text { mm/lst h) }\end{array}$ \\
\hline $\begin{array}{l}\text { Pretreatment RA } \\
\begin{array}{l}\text { Post-treatment } \\
\text { RA }\end{array}\end{array}$ & 1.7 & $106 \cdot 3$ & $57 \cdot 2$ \\
& 1.36 & $72 \cdot 4$ & 46.5 \\
$\mathrm{p}<0.05$ & $\mathrm{NS}$ & $\mathrm{p}<0.05$ \\
\hline
\end{tabular}


not in the duration of morning stiffness. Fig. 1 compares the change in ESR and total urinary GAG excretion in the RA groups pre- and post-treatment. In the seven patients in whom the ESR rose over the study period, the total urinary GAG excretion fell in all but one. In four of these six patients the remaining parameters (morning stiffness and global activity) suggested improvement. In only one patient did the urinary GAG rise while the other parameters fell, but this was one of the two patients with a low pretreatment GAG value.

There were no differences in GAG excretion between the $\mathrm{OA}$ and control groups. In the MI group total urinary GAG excretion was significantly higher than in controls $(\mathrm{p}<0.02)$ and appeared to be due to an excess of high molecular weight GAG when compared with controls $(p<0 \cdot 001)$. From the GAG:creatinine ratio measured on random samples on three successive days postinfarct it was concluded that the high levels were not artefactual and neither were peak levels of urinary GAG being missed by collecting the study sample in the 24 hours postinfarction. By obtaining 24-hour urine samples from all subjects in the main study creatinine estimation was considered unnecessary. There was no difference in day to day variation between the GAG:creatinine ratio or the GAG excretion per 24 hours.

\section{Discussion}

This study shows that there is an increase in total urinary GAG excretion in patients with active RA and in patients after myocardial infarction but no increase in GAG excretion in patients with osteoarthritis. In RA, total urinary GAG excretion falls after response of the disease to second-line drug therapy but appears uninfluenced by treatment with non-steroidal anti-inflammatory drugs. Urinary GAG is thought to be derived from high molecular weight proteoglycans which have probably been released from the parent molecule by proteolytic digestion in vivo. ${ }^{7}$ The method used for the precipitation of GAG complexes has been designed specifically for the measurement of urinary GAG and measures both sulphated and non-sulphated uronic complexes. Thus hyaluronic acid as well as the chondroitin sulphates and heparan sulphate are measured. ${ }^{6}$ The low molecular weight GAG fraction probably indicates further enzymic digestion of high molecular weight GAG. Thus in the present study

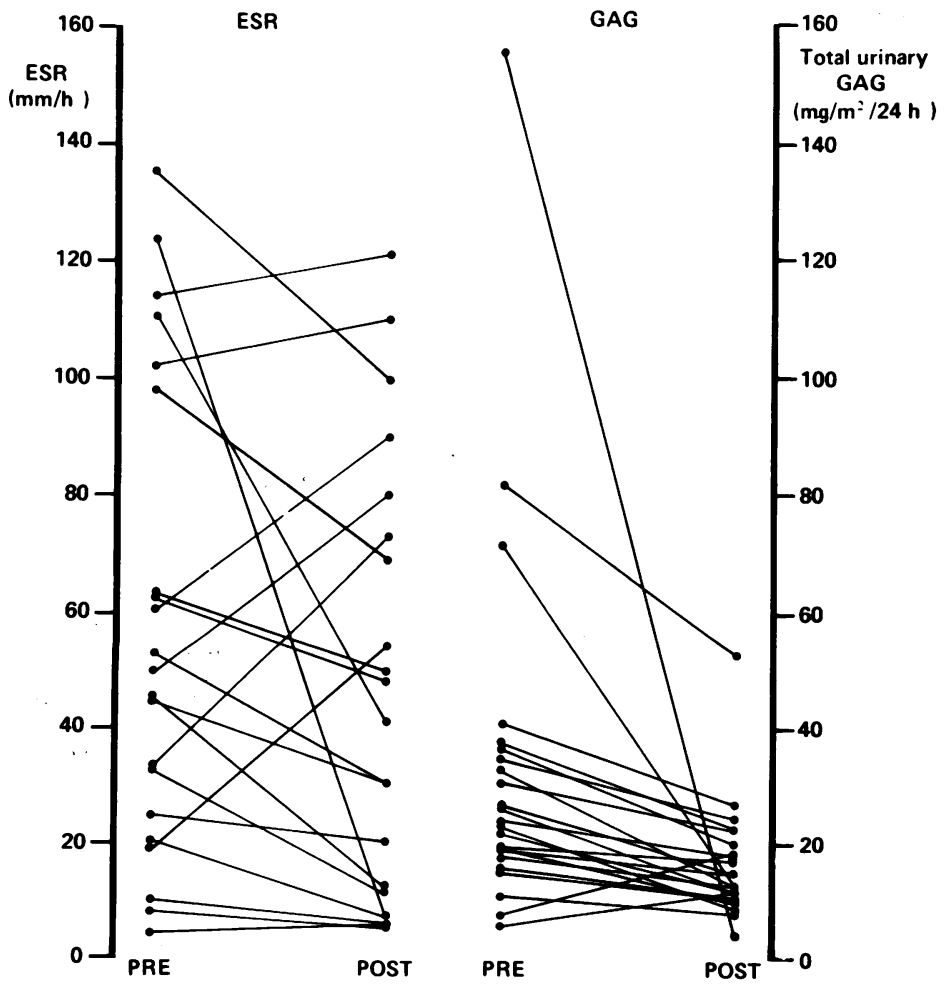

Fig. 1 Changes in ESR and total urinary $G A G$ excretion in the $R A$ group pre- and post-treatment. 
the increase in total urinary GAG excretion in both RA and MI groups probably reflects tissue destruction in both disorders. In the RA group, however, there is a disproportionate increase in the low molecular weight fraction, which could be explained by further local enzymic digestion of GAG released from articular tissues. This interpretation is in keeping with the normalisation of the high molecular weight to low molecular weight GAG fractions with response of the articular disease to the secondline drug therapy. Whether the increase in urinary GAG excretion in RA reflects tissue destruction or not is unproved, and an alternative explanation is that it reflects an overall increase in connective tissue metabolism. This is a less likely explanation of the disproportionate increase in the low molecular weight GAG fraction.

The increased GAG excretion in the MI group is of interest in the light of previous studies which have shown a complex inter-relationship between tissue and plasma GAG, atherosclerosis, and myocardial infarction. The earliest pathological change in lipid deposition and atherosclerosis has been linked with change in GAG composition and concentration in the ground substance of the mesenchyme of the arterial intima and cardiovascular connective tissue. $^{89}$ During the early oedematous reaction following experimentally induced MI in rats an alteration in GAG concentration in heart muscle has been reported. ${ }^{10}$ An increase in chondroitin sulphate in rat heart muscle was found to be associated with the earliest phase of the infarction process, ${ }^{11}$ and similar findings were noted in the dog 10 days after ligation of the circumflex artery. ${ }^{12}$ In view of these findings following $\mathrm{MI}$ it may be that the earliest sign of tissue damage in RA is also an alteration in GAG composition and concentration. However, because of the larger amounts of 'connective tissue' at risk of involvement in an inflammatory condition affecting joints it seems surprising that the urinary GAG levels are not even higher in the active RA group, though this might reflect a more insidious process than the single insult of a myocardial infarction.

Conventional monitoring of disease activity in RA uses several different measures each of which may reflect a different facet of the inflammatory disease process. As urinary GAG excretion is the presumed end point of tissue breakdown and is not an indirect measure (cf. ESR, a composite of various acutephase reactants), it may be a useful addition to conventional assessment techniques. The poor correlation noted between the change in ESR and $\frac{5}{\omega}$ change in urinary GAG excretion before and after second-line drug therapy in our minds invalidates $\stackrel{\sim}{\stackrel{5}{+}}$ neither assessment but rather supports the concept $\bar{O}$ that the two measure different facets of the disease 음 process. There is a wide variation in GAG excretion $\frac{\bar{c}}{\frac{7}{7}}$ in both normal and disease groups, with consider- $\stackrel{\mathbb{Q}}{\varrho}$ able overlap, so that a single GAG measurement is of limited value. Serial measurements in individual patients may, however, be a useful indicator of either increasing activity or of response to secondline therapy.

We thank Dr D Morrison of North Manchester General Hospital for permission to study patients under his care, the University of $G$ Manchester Regional Computer Centre for statistical analysis, and $N$ Miss Catherine Barker for secretarial help.

\section{References}

1 Murata K, Takeda M. Compositional changes in urinary acidic $\overbrace{}^{\top}$ glycosaminoglycans in progressive systemic sclerosis. Clin Chim 음 Acta 1980; 108: 49-59.

2 Di Ferrante N. Urinary excretion of acid mucopolysaccharides by patients with rheumatoid arthritis. J Clin Invest 1957; 36: 1516-20.

3 Firman C, Eronen I, Hämäläinen E. Increased urinary ee cretion of glycosaminoglycans degradation products in rheuma toid arthritis [Abstract]. European Congress on Rheumatolog Paris, 1981; 1077.

4 Mbuyi J, Dequeker J, Teblick M, Merlevede M. Relevance of urinary excretion of alcian-blue-glycosaminoglycans complexes and hydroxyproline to disease activity in rheumatoid arthritis. J Rheumatol 1982; 9: 579-83.

5 Ropes M W, Bennett G A, Cobb S, Jacox R, et al. Revision of diagnostic criteria for rheumatoid arthritis. Arthritis Rheum 1958; 2: 16-20.

6 Whiteman P. The quantitative determination of glycosaminoglycans in urine with alcian blue $8 \mathrm{Gx}$. Biochem $J$ 1973; 131: 351-7.

7 Salposky A K, Howell D S, Woessner J F. Neutral proteases and cathepsin D in human articular cartilage. J Clin Invest 1974; 53: 1044.

8 Gerö S, Bihari-Varga M, Virág S, Vegh M. Investigations of the role of mucopolysaccharides in atherosclerosis. In: Le rôle OO de la paroi artérielle dans l'atherogénèse. Proc 169th Int Coll Cen Nat Rech Sci Paris, 1968: 789-819.

9 Smith E B. Acid glycosaminoglycans, collagen and elastin content of normal artery, fatty streaks and plaques. $A d v \operatorname{Exp} \frac{D}{2}$ Med Biol 1974; 43: 125-39.

10 Judd J T, Wexler B C. Myocardial connective tissue metabolism in response to injury. Circ Res 1970; 26: 101-9.

11 Judd J T, Wexler B C. Sulphur-35 uptake in acid mucopoly- $\mathrm{N}$ saccharides of the rat heart during injury. Am J Physiol 1973; 224: 312-7.

12 Shetlar M R, Davitt W F, Shetlar C L, et al. Glycosaminoglycan changes in healing myocardial infarction. Proc Soc Exp Biol Med 1978; 158: 210-4. 